\title{
Efficiency of different Nitrogen Source, doses and Split application on growth and yield of maize (Zea mays $L$.$) in the$ Malwa region of Madhya Pradesh
}

\author{
*Arun Joshi, **J. K. Gupta,*** S. K. Choudhary, ****D. K. Paliwal \\ *Head, NLRI,Ratlam, MP, **Associate Professor, Ag. Economics,M.G.C.G.V.V.Chitrakoot, Satna, MP \\ ***Professor,Agronomy, College of Agriculture, Indore,MP, S.M.S.Agronomy, KVK,Indore, MP,India
}

\begin{abstract}
The present investigation entitled "Efficiency of different Nitrogen Source, doses and Split application on growth and yield of maize (Zea mays L.) in the Malwa region of Madhya Pradesh" was conducted at Research Farm, National Livelihood Resource Institute, Ratlam (M. P.) during kharif season in 2009 and 2010. The experiment was aimed to find out best source, optimum level and time of nitrogen application. On the basis of the two years experimentation, it can be concluded that for achieving the higher growth and yields with better monetary returns from maize variety JM-216 in the Malwa region of Madhya Pradesh, nitrogen may be applied through Neem coated urea @ $100 \mathrm{~kg} / \mathrm{ha}$ in 3 splits doses i.e. basal, 25 and 45 DAS. This application was found more productive and profitable.
\end{abstract}

Key Words- Doses, Prilled Urea, Granuller Urea, Neem Coated Urea, Split Application,

\section{Introduction}

Maize is a crop par excellence for food, feed and industrial utilization and grown in $7.8 \mathrm{M}$ ha land with $14.05 \mathrm{M}$ tones of production and $1885 \mathrm{~kg} / \mathrm{ha}$ productivity in India under irrigated to Semi-arid conditions. It provides the nutritional security due to its high nutritive values. The low productivity of maize in India is associated with a wide range of production constraints, among them low nitrogen use efficiency is a major constraint. While cultivating the maize crop, the farmers come across various problems like less availability or non availability of the seed, improper irrigation facilities, use of fertilizers, availability of farm yard manure, etc. Among these factors, the imbalanced use of fertilizers especially nitrogen is a major factor. Nitrogen $(\mathrm{N})$ is often the most limiting factor in crop production. Hence, application of fertilizer nitrogen results in higher biomass yields and protein yield and concentration in plant tissue is commonly increased. Nitrogen often affects amino acid composition of protein and in turn its nutritional quality. In maize, abundant supply of nitrogen decreases the relative proportion of lysine and threonine, thus, reducing the biological value of the protein. Increasing nitrogen supply generally improves kernel integrity and strength, resulting in better milling properties of the grain (Blumenthal et al., 2008). Nitrogen is in high demand throughout the growing season. In the first 25 days of a maize plants growth, it will absorb $8 \%$ of its total Nitrogen. This is critical because the corn plant determines the number of kernel rows in the first 25 days of growth. The number of kernel rows can dramatically impact yield, so placement in the root zone is extremely important. Maize is a highly exhaustive crop and it requires high nutrient application particularly nitrogen. Increasing $\mathrm{N}$-fertilizer use efficiency and reducing the leaching losses of nitrogenous fertilizers are some of the options to lower the doses of nitrogen in maize. Application of nitrogenous fertilizers as top dressings at various crop stages, modifying the physical properties of fertilizer granules are possible ways to meet out the options besides lowering the cost of production. Keeping these facts in view, the experiment was conducted in kharif seasons of 2009 and 2010 in Malwa plateau agro-climatic zone of Madhya Pradesh.

Objective- To find out the efficiency of different Nitrogen Source, doses and Split application on growth and yield of maize.

\section{Material And Methods}

The experiment was conducted during Kharif season of 2009-10 and 2010-11 at Research Farm, National Livelihood Resource Institute, Ratlam (Madhya Pradesh). The topography of field was uniform and gentle slope with adequate drainage. It has subtropical climate with a temperature range of $25.5^{\circ} \mathrm{C}$ to $38.2^{\circ} \mathrm{C}$ and $10.7^{\circ} \mathrm{C}$ to $26.5^{\circ} \mathrm{C}$ in summer and winter season respectively. This region belongs to semi arid condition with an average annual rainfall of $960 \mathrm{~mm}$. However the rainfall observed during crop periods was 874.4 and $510 \mathrm{~mm}$ in 2009-10 and 2010-11, respectively. The soil of the field was a typical medium black clayey soil. The soil was low in organic carbon and available nitrogen $(184.5 \mathrm{~kg} / \mathrm{ha})$, medium in available phosphorus $(10.10 \mathrm{~kg} / \mathrm{ha})$ and medium in available potassium ( $338.6 \mathrm{~kg} / \mathrm{ha}$ ) with a pH of 7.76 and $\mathrm{EC}$ of $0.26 \mathrm{dSm}^{-1}$ 
The experiment consisting of the 27 treatment combinations of The experiment consisted of twenty seven treatment combinations of three levels each of the three factors viz. levels, source and schedules of nitrogen application, laid in factorial randomized block design replicated three times. The treatments consisted of 50, 75 and $100 \mathrm{~kg} \mathrm{~N} / \mathrm{ha}$ in the form of Prilled urea, Granular urea and Neem coated urea applied either in single dose at sowing or in two split (basal and 25 DAS) or in three split (basal, 25 and 45 DAS). A common dose of $40 \mathrm{~kg} \mathrm{P}_{2} \mathrm{O}_{5}$ and $40 \mathrm{~kg} \mathrm{~K} \mathrm{~K}_{2} \mathrm{O} / \mathrm{ha}$ was applied at sowing. Full dose of $\mathrm{P}_{2} \mathrm{O}_{5}$ and $\mathrm{K}_{2} \mathrm{O}$ was given through complex fertilizer and the remaining quantity of $\mathrm{N}$ as per treatment was given through Granular urea, Prilled urea and Neem coated urea. The experiment was carried out in a Factorial Randomized block design and analysed statistically as per procedure suggested by Panse and Sukhatme (1978). Standard package of practices and observation patterns were followed during both of the years of experimentations.

\section{Results And Discussions}

The Table 1 revealed that the growth parameters, viz., plant height, number of leaves per plant, leaf area, fresh and dry weight per plant and chlorophyll content were significantly higher with the application of nitrogen through Neem coated urea than the Granular urea and Prilled urea. This may be due to the fact that coating of urea decreases the leaching loses and provide more nitrogen to the plant (Chaudhari et al., 2006). Similar findings were also obtained by Palled and Shenoy (2000).

Table 1. Observation on various growth characters (pooled data of the two years)

\begin{tabular}{|c|c|c|c|c|c|c|}
\hline Treatment & $\begin{array}{c}\text { Plant } \\
\text { height } \\
\text { (cm) }\end{array}$ & $\begin{array}{c}\text { Numbers of } \\
\text { leaves per } \\
\text { plant }\end{array}$ & $\begin{array}{l}\text { Leaf } \\
\text { area } \\
\left(\mathrm{cm}^{2}\right)\end{array}$ & $\begin{array}{c}\text { Fresh } \\
\text { weight } \\
\text { per plant } \\
\text { (g) }\end{array}$ & $\begin{array}{c}\text { Dry weight } \\
\text { per plant }(g)\end{array}$ & $\begin{array}{c}\text { Chlorophyll } \\
\text { content (SPAD) }\end{array}$ \\
\hline \multicolumn{7}{|l|}{$\begin{array}{l}\text { Source of } \\
\text { nitrogen }\end{array}$} \\
\hline Prilled urea & 163.55 & 11.45 & 1174.4 & 569.5 & 164.2 & 39.71 \\
\hline Granular urea & 171.82 & 12.06 & 1236.4 & 601.7 & 173.0 & 41.85 \\
\hline NC urea & 173.34 & 12.10 & 1241.4 & 602.7 & 173.6 & 42.05 \\
\hline SEm \pm & 2.45 & (2.17 & 10 & 8.4 & 2.33 & 0.56 \\
\hline C.D. (at 5\%) & 6.95 & 0.47 & 50.3 & 23.8 & 6.60 & 1.59 \\
\hline \multicolumn{7}{|l|}{$\underline{\underline{\text { Level of }}}$} \\
\hline $50 \mathrm{~kg} \mathrm{~N} / \mathrm{ha}$ & 165.35 & 11.55 & 1186.8 & 573.4 & 165.9 & 40.08 \\
\hline $75 \mathrm{~kg} \mathrm{~N} / \mathrm{ha}$ & 167.74 & 11.76 & 1204.0 & 587.1 & 168.6 & 41.00 \\
\hline $100 \mathrm{~kg} \mathrm{~N} / \mathrm{ha}$ & 175.62 & 12.31 & 1261.4 & 613.4 & 176.2 & 42.54 \\
\hline SEm \pm & 2.45 & 0.17 & 17.7 & 8.4 & 2.33 & 0.56 \\
\hline C.D. (at 5\%) & 6.95 & 0.47 & 50.3 & 23.8 & 6.60 & 1.59 \\
\hline \multicolumn{7}{|l|}{$\begin{array}{l}\text { Scheduling of } \\
\text { nitrogen }\end{array}$} \\
\hline Basal only & 162.01 & 11.31 & 1164.4 & 564.4 & 162.7 & 39.41 \\
\hline 2-splits & 170.07 & 11.96 & 1224.6 & 594.5 & 171.4 & 41.56 \\
\hline 3-splits & 176.63 & 12.34 & 1263.2 & 615.0 & 176.7 & 42.64 \\
\hline SEm \pm & 2.45 & 0.17 & 17.7 & 8.4 & 2.33 & 0.56 \\
\hline C.D. (at 5\%) & 6.95 & 0.47 & 50.3 & 23.8 & 6.60 & 1.59 \\
\hline
\end{tabular}

Increase in level of nitrogen from $50 \mathrm{~kg}$ to $100 \mathrm{~kg} / \mathrm{ha}$ significantly increased the plant height, number of leaves/plant, leaf area, fresh and dry weight per plant and chlorophyll content at all stages of observation. The significant improvement in various growth parameters might be attributed to the fact that nitrogen helps in maintaining higher auxin level which might have resulted in better plant height, number of leaves per plant, leaf area and presumably chlorophyll content of the leaves. This might have resulted into better interception, absorption and utilization of radiant energy, leading to higher photosynthetic rate and finally more accumulation of fresh as well as dry matter by the plants. The increases in growth parameters with increasing levels of nitrogen have also been reported by Mehrabadi and Mohassel (2000) and Kaur et al. (2012), Li Zhen et al. (2012). Scheduling of nitrogen significantly affected the most of the growth parameters at all growth stages of crop. Application of $\mathrm{N}$ in three splits (basal, 25 and $45 \mathrm{DAS}$ ) significantly increased these growth parameters compared to application in two splits (basal and 25 DAS) and in basal (at the time of sowing). The possible reason for the increase in the growth parameters by three splits application of nitrogen might be due to more accumulation of nitrogen content in plant which in turn resulted in more synthesis of nucleic acids, amino acids, amide substances in growing regions of meristematic tissues ultimately enhanced multiplication of cell division 
and there by increased in the growth attributes. Similar results were recorded by Palled and Shenoy (2006). Interaction effect of level and scheduling of nitrogen application mostly found statistically non-significant.

Table 2. Observation on various yield characters and yield (pooled data of the two years)

\begin{tabular}{|c|c|c|c|c|c|c|}
\hline$\underline{\text { Treatment }}$ & $\begin{array}{c}\text { No. of } \\
\text { grains /cob }\end{array}$ & $\begin{array}{c}\text { Weight per cob } \\
(\mathrm{g})\end{array}$ & $\begin{array}{c}\text { Seed } \\
\text { index }(g)\end{array}$ & $\begin{array}{l}\text { Grain } \\
\text { yield } \\
\text { (kg/ha) }\end{array}$ & $\begin{array}{c}\text { Straw yield } \\
(\mathrm{kg} / \mathrm{ha})\end{array}$ & Harvest index (\%) \\
\hline \multicolumn{7}{|l|}{$\begin{array}{l}\text { Source of } \\
\text { nitrogen } \\
\end{array}$} \\
\hline Prilled urea & 425.76 & 151.19 & 24.89 & 5245.45 & 8734.46 & 37.52 \\
\hline Granular urea & 449.89 & 158.92 & 26.22 & 5539.26 & 9157.41 & 37.68 \\
\hline NC urea & $\begin{array}{l}453.13 \\
\end{array}$ & $\begin{array}{c}160.10 \\
\end{array}$ & 26.48 & 5568.83 & 9231.24 & 37.63 \\
\hline SEm \pm & 6.13 & 2.13 & 0.35 & 77.20 & 123.04 & 0.08 \\
\hline C.D. (at 5\%) & 17.40 & (6.06 & 1.01 & 219.08 & 349.16 & NS \\
\hline \multicolumn{7}{|l|}{$\frac{\text { Level of }}{\text { nitrogen }}$} \\
\hline$\overline{50 \mathrm{~kg} \mathrm{~N} / \mathrm{ha}}$ & 430.48 & 152.82 & 25.18 & 5279.90 & 8792.31 & 37.51 \\
\hline $75 \mathrm{~kg} \mathrm{~N} / \mathrm{ha}$ & 439.54 & 155.32 & 25.65 & 5407.64 & 8968.18 & 37.62 \\
\hline $100 \mathrm{~kg} \mathrm{~N} / \mathrm{ha}$ & 458.76 & 162.06 & 26.76 & 5665.99 & 9362.62 & 37.69 \\
\hline SEm \pm & 6.13 & 2.13 & 0.35 & 77.20 & 123.04 & 0.08 \\
\hline C.D. (at 5\%) & $\begin{array}{c}17.40 \\
\end{array}$ & 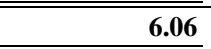 & 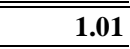 & 219.08 & $\overline{349.16}$ & NS \\
\hline \multicolumn{7}{|l|}{$\begin{array}{l}\text { Scheduling of } \\
\text { nitrogen }\end{array}$} \\
\hline Basal only & 423.50 & 150.12 & 24.71 & 5212.37 & 8647.15 & 37.60 \\
\hline 2-splits & 445.64 & 157.68 & 26.02 & 5497.84 & 9096.74 & 37.67 \\
\hline 3-splits & 459.65 & 162.41 & 26.86 & 5643.33 & 9379.23 & 37.56 \\
\hline SEm \pm & 6.13 & 2.13 & 0.35 & 77.20 & 123.04 & 0.08 \\
\hline C.D. (at 5\%) & 17.40 & $\overline{6.06}$ & 1.01 & 219.08 & 349.16 & NS \\
\hline
\end{tabular}

Sources of nitrogen significantly affected the yield components. Use of Neem coated urea as source of nitrogen resulted in significantly highest grains per cob, weight per cob and seed index over Granular urea and Prilled urea. Granular urea was found comparable to Neem coated urea in respect of number of grains per cob and weight per cob. This may be due to increased plant growth characters upto significant level by increased availability of nitrogen to plants. The beneficial effect of Neem coated urea decreases nitrogen losses and provides slow release of nitrogen to plant. Similar results on yield components have also been reported by Budhar et al. (1991). Neem coated urea produced 6.16 per cent more seed yield than Prilled urea in pooled data and exhibited its superiority over both later sources of nitrogen. Application of Neem coated urea as a source of nitrogen also resulted in significantly highest seed yield over rest of the sources. Similar effects of Neem coated urea were also observed on straw yield. Higher recovery of nitrogen may be possible when the nitrogen is made available to the plant over longer periods and by reducing nitrogen losses.

Nitrogen fertilization at $100 \mathrm{~kg}$ per hectare brought significant improvement in yield attributing traits as compared to $75 \mathrm{~kg} \mathrm{~N} / \mathrm{ha}$. The overall improvement in crop growth was reflected into better development of sink i.e. yield attributes. The excellent utilization of growth resources particularly nitrogen in absolute amount on account of better availability in well supplied plots (100 kg N/ha) and later their translocation to sink during the course of grain filling stage might have caused superiority in aforesaid yield attributing characters as compared to plots supplied with sub-optimal level of nitrogen $(75 \mathrm{~kg} \mathrm{~N} / \mathrm{ha})$. Adequate supply of $\mathrm{N}$ might have caused increase in grains per cob. Higher accumulation of photosynthates at $100 \mathrm{~kg} \mathrm{~N} / \mathrm{ha}$ resulted in relatively higher accumulation of photosynthates in individual grain and thereby also increased the 100 grain weight (seed index) and ultimately weight of cob at higher level of $\mathrm{N}(100 \mathrm{~kg} / \mathrm{ha})$. Application of nitrogen at $100 \mathrm{~kg} / \mathrm{ha}$ increased the seed yield by 4.78 per cent over $75 \mathrm{~kg} \mathrm{~N} / \mathrm{ha}$. Similar trend was observed for straw yield. The findings of Carvalho et al., 2012, and Wasnik et al. (2012) also confirms these results. These yield attributing traits and yield were also varied significantly due to scheduling of nitrogen. Number of grain per cob and weight per cob were increased with an increase in frequency of nitrogen application and were the highest with the three splits application of nitrogen. Application of nitrogen in three splits registered the maximum values of these parameters and proved significantly superior to the nitrogen application in two splits and basal. Application of nitrogen in three splits registered the maximum seed and straw yields and proved significantly superior to the nitrogen application in two splits and basal. Seed yield was recorded 2.65 per cent higher under three splits over only basal application. Three split application at basal, 25 and 45 DAS maintained continuous supply of nutrients which might have favored the crop for higher values of yield attributes. These results are in close 
conformity with those of Palled and Shenoy (2006). However, the harvest index was not observed to be affected significantly due to various sources, levels and schedule of application of nitrogen.

\section{References}

[1] Blumenthal Jürg M., David D., Baltensperger, Kenneth G., Cassman, Stephen C. Mason and Alexander D. Pavlista (2008). Importance and Effect of Nitrogen on Crop Quality and Health. Nitrogen in the Environment: Sources, Problems, and Management, Second edition :51-70

[2] Budhar, M.N., Ramaswami, C. and Abdul Kareem, A. 1991. Relative efficiency of coated N fertilizers in lowland rice. Indian J. Agron. 36: 124-125.

[3] Carvalho, E. V.; de Afferri, F. S.; Peluzio, J. M.; Dotto, M. A. and Cancellier, L. L. (2012). Nitrogen use efficiency in corn (Zea mays L.) genotypes under different conditions of nitrogen and seeding date. Maydica; 2012. 57: 1, 43-48.

[4] Chaudhari, P.M., Patil, H.E., and Hankare, R.H. 2006. Effect of integrated nitrogen management in maize (Zea may L.) on pattern of leaf area and dry matter production. International J. Plant Sci., 1 (1):17-20.

[5] Kaur Amandeep; Bedi Seema; Gill, G. K. and Mahesh Kumar (2012). Effect of nitrogen fertilizers on radiation use efficiency, crop growth and yield in some maize (Zea mays L.) genotypes. Maydica; 2012. 57: 1, 75-82.

[6] Li Zhen An, HongMing Su, Kai Liu, Peng Zhang, JiWang and Dong ShuTing (2012). Study on red edge characteristics of summer maize and their correlation to chlorophyll and dry matter. Journal of Maize Sciences; 2012. 20: 2, 87-91

[7] Mehrabadi, H.R., Mohassel, M.H.R. 2000. Effect of urea foliar application time on growth indices, yield, yield components and quality parameters of two grain corn cultivars. Seed and Plant. 15(4):pp.413-426, en39.

[8] Palled, Y.B. and Shenoy, H. 2006. Effect of nitrification inhibitors and time of nitrogen application on hybrid maize. CurrentResearch-Univ. -Agril-Sci. Bangalore. 29(1/2):19.20.

[9] Panse, V.C. and Sukhatme, P.V. (1967). Statistical methods for agricultural workers. ICAR Publications, New Delhi.

[10] Wasnik, V. K. Reddy, A. P. K. and Kasbe, S. S. (2012). Performance of winter maize under different rates of nitrogen and plant population in Southern Telangana region. Crop Research (Hisar); 2012. 44: 3, 269-273. 